\title{
Web-Based Integrated Disaster Information System For Optimizing The Role and Function of The Data and Information Center (PUSDATIN) Badan Penanggulangan Bencana Daerah Kabupaten Sidoarjo
}

\author{
Dini Aprilia Puspitasari ${ }^{1)}$, Ade Eviyanti ${ }^{2)}$ \\ \{aprilia.dini@gmail.com¹ , adeeviyanti@umsida.ac.id ${ }^{2}$ \}
}

Program Studi Informatika, Fakultas Sains dan Teknologi, Universitas Muhammadiyah Sidoarjo

\begin{abstract}
The Data and Information Center (PUSDATIN) is the main facility for disaster management. Integrated data is the main support in determining disaster management policies. The purpose of research is to built an integrated disaster information system to optimize the function of PUSDATIN. The research method used was interviews and data collection. This system was developed using MySQL and Dreamweaver. There are 3 (three) user levels : user, admin and super admin. The result is an integrated disaster information system on web-based that can be accessed by anyone, according to the level of user, users can execute CRUD commands smoothly, data redundancies can be reduced, and optimization of BPBD resources by using PUSDATIN as 1 (one) gate data. The conclusion of this research is this web-based integrated disaster information system running well and has a positive effect on the performance of PUSDATIN as a traffic data center for disasters and fires.
\end{abstract}

Keywords - BPBD; disaster management; information system; integrated data; PUSDATIN

\begin{abstract}
Abstrak. Pusat Data dan Informasi (PUSDATIN) merupakan sarana utama pada instansi penanggulangan bencana. Data yang terintegrasi menjadi penopang utama dalam penentuan kebijakan penanggulangan bencana. Tujuan dari penelitian adalah untuk membangun sistem informasi kebencanaan terpadu untuk mengoptimalkan fungsi PUSDATIN pada pelayanan BPBD Kabupaten Sidoarjo. Metode penelitian yang digunakan wawancara dan pengumpulan data. Sistem ini dikembangkan menggunakan MySQL dan Dreamweaver. Terdapat 3 (tiga) level pengguna yaitu user, admin dan super admin. Hasil dari penelitian ini adalah adanya sistem informasi kebencanaan berbasis web yang dapat diakses oleh siapa saja, sesuai dengan level usernya. Hasil uji coba / implementasi pada sistem informasi mempermudah user dalam mengeksekusi perintah CRUD dengan lancar.redudansi data dapat dikurangi, serta optimalisasi sumber daya BPBD dengan pemanfaatan PUSDATIN sebagai akses data 1 (satu) pintu. Kesimpulan dari penelitian ini adalah sistem informasi kebencanaan terpadu ini berjalan dengan baik dan berpengaruh positif terhadap kinerja PUSDATIN sebagai pusat lalu lintas data bencana dan kebakaran.
\end{abstract}

Kata kunci-BPBD; data terintegrasi; manajemen bencana; PUSDATIN; sistem informasi

\section{Pendahuluan}

Sesuai dengan Undang-Undang Nomor 24 Tahun 2007 tentang Penanggulangan Bencana, disebutkan bahwa pemerintah dan pemerintah daerah bertanggung jawab dalam penyelenggaraan penanggulangan bencana, dimulai dari tahapan pra bencana, saat bencana sampai dengan pasca bencana [8].

Saat ini, data bencana yang tersedia di BPBD Kabupaten Sidoarjo belum terintegrasi dengan baik, dimana format data / informasi kebencanaan bermacam-macam, belum terintergrasi, tumpang tindih serta masih diolah secara manual. Oleh karena itu diperlukan suatu sistem yang dapat menyajikan informasi secara terpadu, menyeluruh serta dapat diakses dimana saja dan kapan saja. Pengelolaan data kebencanaan satu pintu di BPBD Kabupaten Sidoarjo setelah dilakukan verifikasi dan validasi pada waktu tertentu diolah oleh Pusat Data dan Informasi (PUSDATIN) BPBD Kabupaten Sidoarjo. Kebijakan ini dilakukan untuk menghindari duplikasi, kerancuan atau kesimpangsiuran data dan informasi bencana bagi pengambilan keputusan. Data kebencanaan dimaksud meliputi data kejadian bencana berdasarkan periode tertentu, data kejadian kebakaran, data wilayah dan korban terdampak, data bantuan logistik, data personil, data kebutuhan pasca bencana, dll.

Aplikasi ini dirancang dengan batasan sistem informasi yang memiliki 3 (tiga) pengguna yaitu user, admin dan super admin. Sistem Informasi dirancang dalam bentuk website, database dibangun menggunakan mysql dan bahasa pemrograman yang digunakan adalah PHP. Sedangkan untuk data yang digunakan adalah data kejadian bencana tahun 2019 s.d. 2020. Tujuan dari penelitian ini adalah :

- Akurasi data secara terintegrasi (satu pintu) yaitu PUSDATIN BPBD Kabupaten Sidoarjo, data tidak lagi terpisahpisah di bidang; 
- Menghindari data yang bias atau tumpang tindih;

- Membangun sistem informasi berbasis web untuk menyajikan data kebencanaan secara terpadu agar dapat diakses dimana saja dan kapan saja

Sedangkan manfaat yang diharapkan dari penelitian ini adalah terbangunnya sistem informasi yang dapat memaksimalkan fungsi dan peran PUSDATIN BPBD Kabupaten Sidoarjo sebagai pusat data yang terintegrasi dan dapat dimanfaatkan sebagai pendukung pengambilan keputusan dalam penanganan bencana di Kabupaten Sidoarjo.

\section{A. Penelitian terdahulu}

Beberapa penelitian terdahulu [6],[13] yang bermanfaat sebagai rujukan dalam penelitian adalah :

Tabel 1. Penelitian Terdahulu

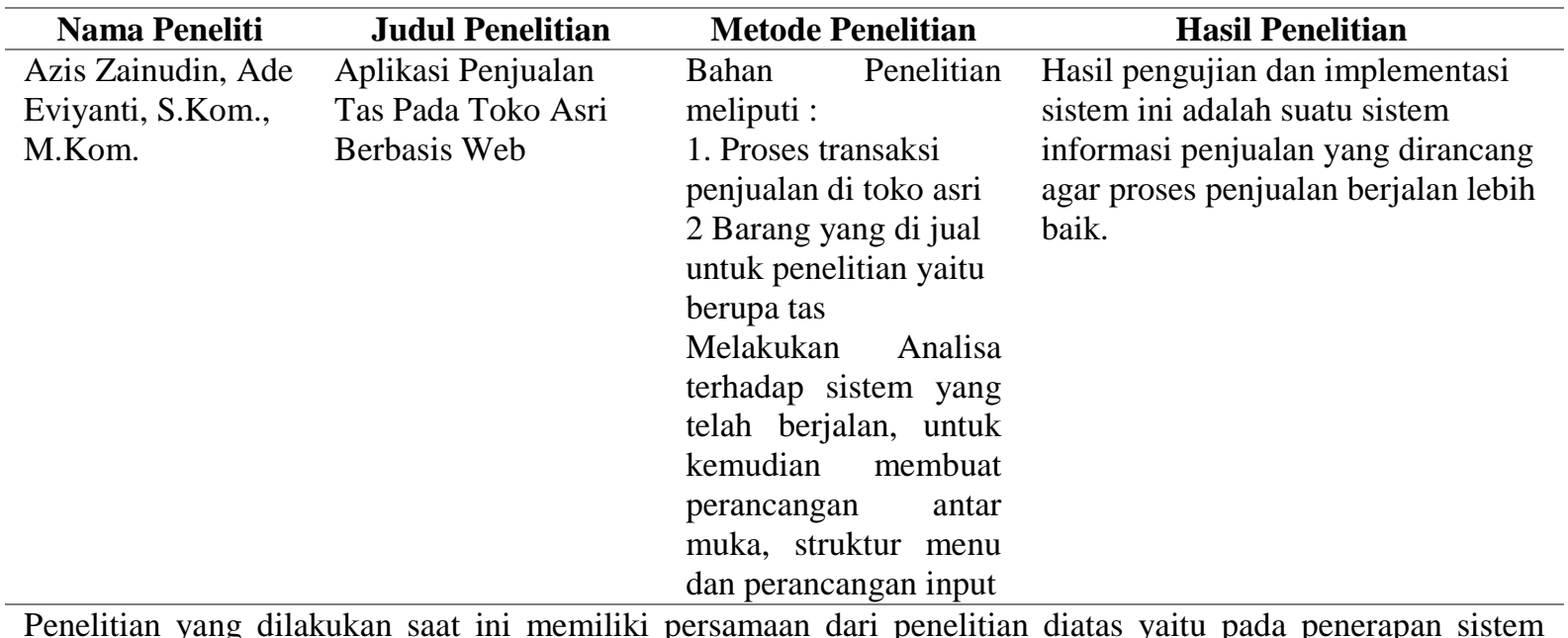

Penelitian yang dilakukan saat ini memiliki persamaan dari penelitian diatas yaitu pada penerapan sistem informasi menggunakan website

\begin{tabular}{|c|c|c|c|}
\hline $\begin{array}{l}\text { Misbakhul Islami, } \\
\text { Ade Eviyanti, } \\
\text { S.Kom., M.Kom. }\end{array}$ & $\begin{array}{l}\text { Rancang Bangun } \\
\text { Aplikasi Terintegrasi } \\
\text { Untuk Pelayanan } \\
\text { Puskesmas } \\
\text { Menggunakan } \\
\text { Framework } \\
\text { Codeigniter }\end{array}$ & $\begin{array}{l}\text { Teknik Analisa, } \\
\text { Perancangan Desain } \\
\text { Sistem yang } \\
\text { meliputi : Analisa } \\
\text { Data, Perancanaan } \\
\text { Input, Perancangan } \\
\text { Proses dan } \\
\text { Perancangan Output } \\
\text { serta dilanjut dengan } \\
\text { Perancangan } \\
\text { Aplikasi } \\
\text { menggunakan } \\
\text { Framework } \\
\text { Codeignitier }\end{array}$ & $\begin{array}{l}\text { Aplikasi yang dibuat adalah aplikasi } \\
\text { berbasis web dengan framework } \\
\text { codeigniter. Aplikasi mempunyai } \\
\text { modul untuk pendaftaran dan } \\
\text { penerimaan pasien yang berkunjung } \\
\text { berobat, pencatatan keluhan, sampai } \\
\text { menjadi data rekam medis pasien. } \\
\text { Data pasien yang sudah di inputkan } \\
\text { akan diproses menjadi sebuah } \\
\text { laporan, yang dimana ada laporan } \\
\text { data pasien, laporan kunjungan } \\
\text { pasien perbulan, dan laporan } \\
\text { kunjungan penerimaan pasien per } \\
\text { poli. }\end{array}$ \\
\hline
\end{tabular}

Penelitian yang dilakukan saat ini memiliki persamaan dari penelitian diatas yaitu pada penerapan sistem informasi menggunakan website, menggunakan mySQL dan PHP serta memiliki proses bisnis yang mirip misalnya pengelolaan user (dalam penelitian ini adalah pasien) sampai dengan adanya menu laporan.

\section{METODE}

\section{A. Analisa sistem}

Untuk membangun sebuah sistem informasi ini, analisa sistem dilakukan melalui 3 (tiga) cara, yaitu :

Observasi

Observasi dilakukan dengan melakukan kajian/penelitian terhadap proses bisnis yang berlaku di BPBD dalam proses penanggulangan bencana dan kebakaran serta pengamatan / analisa terhadap data-data riil di lapangan. Dalam penelitian ini dilakukan observasi langsung di Kantor Badan Penanggulangan Bencana Daerah Kabupaten Sidoarjo.

Wawancara

Dalam teknik wawancara ini peneliti mendengarkan informasi yang telah di dapat dari narasumber dengan seksama dan cermat serta mencatat apa yang diperlukan dalam proses pengumpulan data. Narasumber dimaksud 
adalah pegawai pada Badan Penanggulangan Bencana Daerah Kabupaten Sidoarjo yang telah diberikan kewenangan pimpinan untuk memberikan data dan informasi yang diperlukan dalam penelitian ini.

Studi pustaka

Studi Pustaka diperlukan untuk mencari referensi yang dibutuhkan untuk membangun sistem, yang didapatkan dari berbagai sumber seperti buku, jurnal dan sumber lainnya.

\section{B. Perancangan sistem}

Flowchart / diagram alir

Diagram Alir atau Flowchart adalah sekumpulan gambar dari urutan langkah-langkah dalam suatu proses [2]. Langkah yang berbeda ditunjukkan oleh gambar atau simbol yang berbeda [2]. Diagram alir berikut ini menggambarkan alur / tahapan yang akan dilalui oleh pengguna / user dalam mengakses sistem. Hak akses user berbeda-beda sesuai dengan kewenangannya.

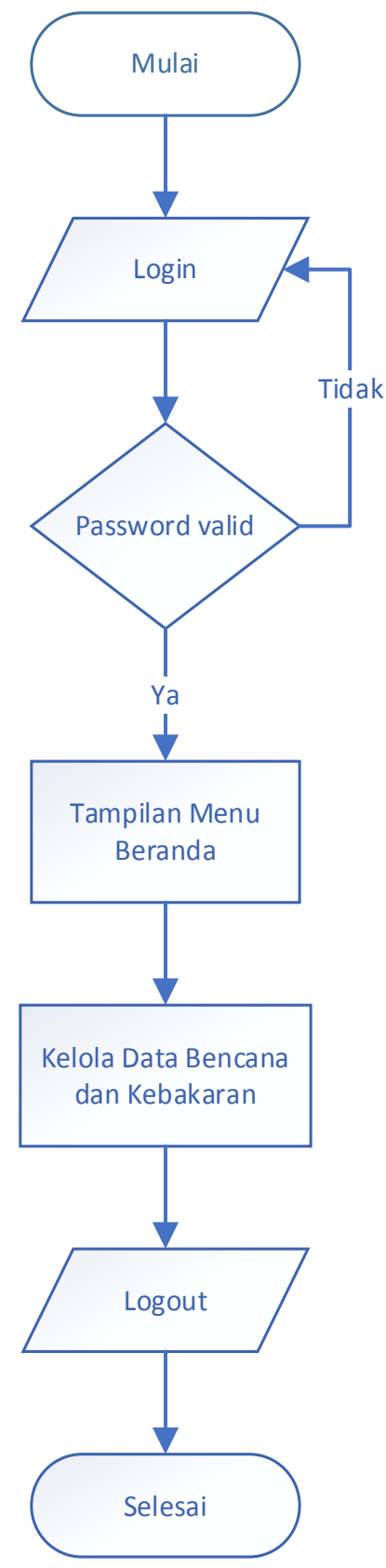

Gambar 1. Flowchart untuk User 
Flowchart Admin

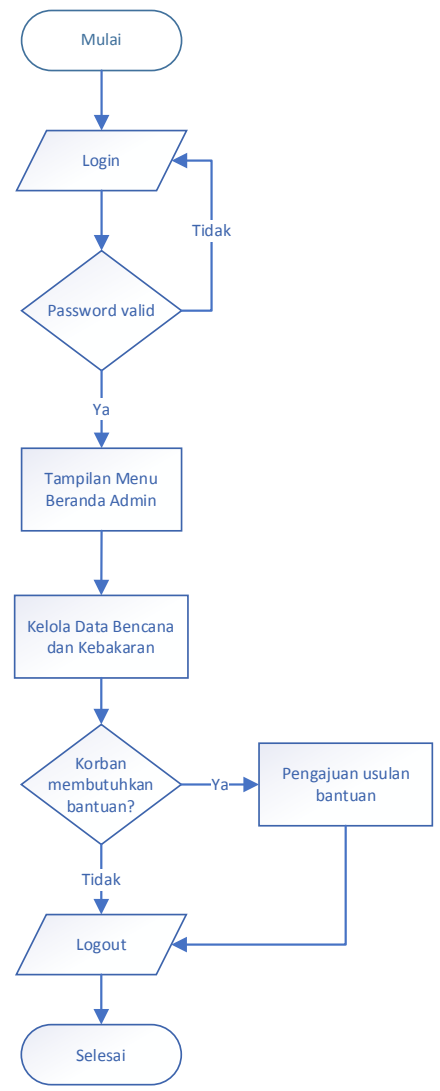

Flowchart Super Admin

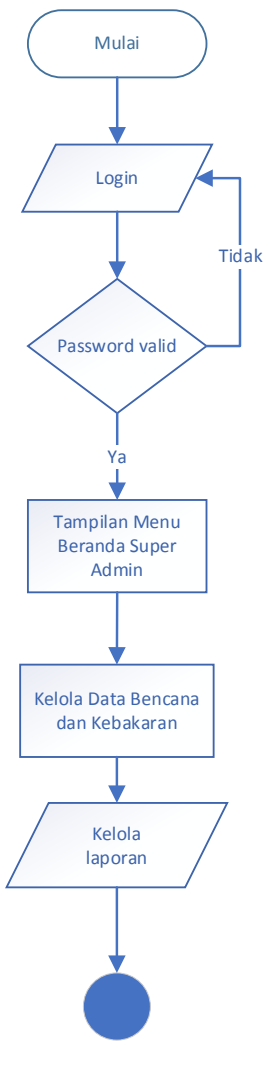

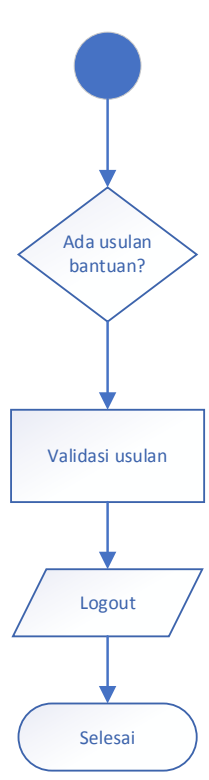

Gambar 2. Flowchart untuk Admin dan Super Admin

\section{Diagram context}

Context Diagram berikut ini menggambarkan aliran data yang masuk dan keluar (input dan output) pada saat pengguna dan admin mengakses sistem.

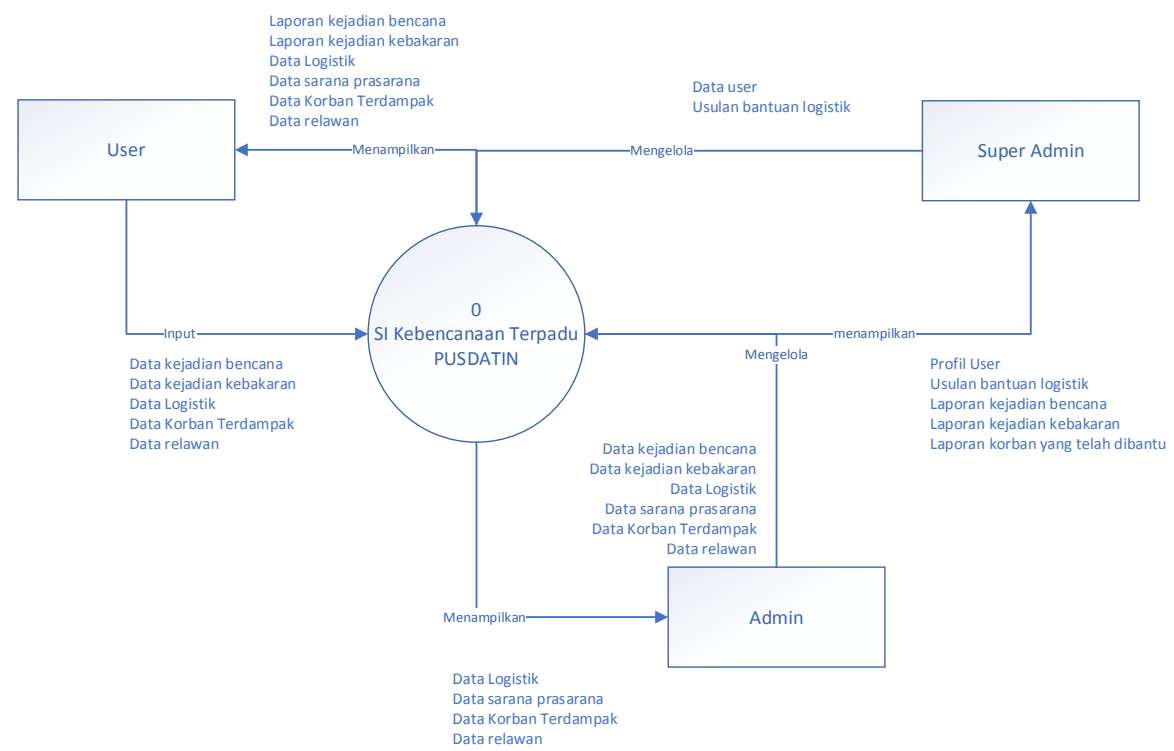

Gambar 3. Diagram Context Sistem Informasi Kebencanaan 
Data flow diagram (DFD)

DFD merupakan aliran data dalam sebuah sistem. DFD menggambarkan data yang tersimpan dengan proses yang ada. Tidak ada loop atau cabang dalam DFD. DFD pada sistem ini terdapat 2 (dua) yaitu Level 0 dan Level 1. DFD Level 0 menjabarkan proses-proses yang terdapat pada sistem secara keseluruhan, sedangkan DFD Level 1 menggambarkan detail dari masing-masing proses yang terdapat pada level 0 .

\section{Perancangan database}

Berdasarkan Data Flow Diagram (DFD) yang telah dibuat sebelumnya, dapat diketahui data-data yang dibutuhkan adalah sebagai berikut :

- Data kejadian bencana : berisi data-data kejadian bencana

- Data kejadian kebakaran : berisi data-data kejadian kebakaran

- Data logistik : berisi data stok logistik yang dimiliki oleh BPBD, yang bisa digunakan untuk membantu korban bencana

- Data sarana prasarana : berisi data sarana prasarana yang digunakan pada pelaksanaan penanggulangan bencana dan kebakaran (bukan data asset BPBD secara keseluruhan)

- Data korban bencana : berisi data-data korban bencana terdampak

- Data korban kebakaran : berisi data-data korban kebakaran

- Data pengguna : berisi data-data korban bencana yang diusulkan ke pimpinan untuk mendapatkan bantuan logistik

- Data usulan bantuan : berisi data usulan bantuan, yang diusulkan oleh Admin dan di validasi oleh Super Admin

Entity relationship diagram (ERD)

Berisi skema / diagram untuk mendeskripsikan data-data atau objek-objek yang dibuat berdasarkan dan berasal dari dunia nyata yang disebut entitas (entity) serta hubungan (relationship) antar entitas-entitas tersebut dengan menggunakan beberapa notasi [3]. Misalnya hubungan yang terjadi antara data kejadian bencana dengan korban bencana adalah one to many, yang artinya dalam 1 (satu) kejadian bencana dapat berdampak pada beberapa orang / korban.

Perancangan desain user interface (UI)

Pada tahapan ini dibuat rancangan desain user interface (UI) dengan tampilan yang menarik dan memudahkan user untuk mengoperasikan sistem. Setelah desain UI dibuat, dilanjutkan dengan pembuatan website menggunakan PHP dan XAMPP sebagai server. PHP (Hypertext Prepocessor) merupakan bahasa / script yang dijalankan pada sisi server (SSS : Server Side Scripting) [4].

\section{Hasil dan Pembahasan}

\section{A. Pengujian sistem}

Metode pengujian sistem yang digunakan adalah black box testing, dimana dilakukan pengujian yang didasarkan pada detail aplikasi seperti tampilan / layout, fungsi-fungsi pada aplikasi, dan kesesuaian alur fungsi dengan proses bisnis yang diinginkan oleh user. Teknik yang digunakan adalah Boundary Value Analysis, dimana teknik ini dinilai paling relevan dengan Sistem Informasi Kebencanaan yang dibangun. Untuk pengujian, data yang digunakan dalam pengujian sistem ini adalah :

1. Data kejadian bencana yang terjadi pada kurun waktu 1 Januari - 31 Desember 2019, serta 1 Januari - 31 Desember 2020. Data yang berkaitan dengan data bencana ini adalah data korban bencana.

2. Data kejadian kebakaran yang terjadi pada kurun waktu 1 Januari - 31 Desember 2019, serta 1 Januari - 31 Desember 2020. Data yang berkaitan dengan data kebakaran ini adalah data korban kebakaran.

3. Data Sarana Prasarana yang ada di BPBD Kabupaten Sidoarjo, yang digunakan hanya dalam kegiatan penanggulangan bencana dan kebakaran, dan bukan data asset keseluruhan.

4. Data Logistik yang tersedia di gupdang logistik Pos Damkar Unit Buduran, Sidoarjo dan masih tercatat pada data persediaan BPBD Kabupaten Sidoarjo.

Secara keseluruhan, hasil pengujian sistem ini menunjukkan hasil yang sesuai dengan harapan. Berikut ini adalah hasil uji sistem pada pengguna dengan level Admin : 
Procedia of Engineering and Life Science Vol.1 No. 1 March 2021

Seminar Nasional \& Call for Paper Fakultas Sains dan Teknologi (SENASAINS 1st)

Universitas Muhammadiyah Sidoarjo

Tabel 2. Hasil Black Box Testing pada Sistem Informasi Kebencanaan pada Admin

\begin{tabular}{|c|c|c|c|}
\hline \multicolumn{4}{|c|}{ Hasil Pengujian Data Normal / Benar } \\
\hline $\begin{array}{l}\text { Aktivitas } \\
\text { Pengujian }\end{array}$ & Realisasi yang Diharapkan & Hasil Pengujian & Kesimpulan \\
\hline Login & $\begin{array}{l}\text { Admin masuk ke halaman Home } \\
\text { Admin }\end{array}$ & Muncul halaman Home Admin & $\begin{array}{l}\text { [x] Diterima } \\
\text { [ ] Ditolak }\end{array}$ \\
\hline $\begin{array}{l}\text { Input Data } \\
\text { (Bencana, } \\
\text { Kebakaran, korban, } \\
\text { sarana prasarana, } \\
\text { logistik) }\end{array}$ & $\begin{array}{l}\text { Data berhasil masuk ke tabel } \\
\text { sesuai record dan kolom }\end{array}$ & $\begin{array}{l}\text { Data masuk ke tabel sesuai record } \\
\text { dan kolom }\end{array}$ & $\begin{array}{l}\text { [x] Diterima } \\
\text { [] Ditolak }\end{array}$ \\
\hline $\begin{array}{l}\text { View data (bencana, } \\
\text { Kebakaran, korban, } \\
\text { sarana prasarana, } \\
\text { logistic, usulan } \\
\text { bantuan) }\end{array}$ & $\begin{array}{l}\text { Tampil data urut sesuai tanggal } \\
\text { kejadian dan id }\end{array}$ & $\begin{array}{l}\text { Tampil data urut sesuai tanggal } \\
\text { kejadian dan id }\end{array}$ & $\begin{array}{l}\text { [x] Diterima } \\
\text { [ ] Ditolak }\end{array}$ \\
\hline $\begin{array}{l}\text { Membuat usulan } \\
\text { bantuan }\end{array}$ & $\begin{array}{l}\text { Link "Usulkan" pada data korban } \\
\text { bencana berfungsi secara benar, } \\
\text { data korban bencana yang } \\
\text { diusulkan masuk ke tabel } \\
\text { usulan_bantuan }\end{array}$ & $\begin{array}{l}\text { Data korban bencana yang } \\
\text { diusulkan berhasil masuk ke tabel } \\
\text { usulan_bantuan }\end{array}$ & $\begin{array}{l}\text { [x] Diterima } \\
\text { [ ] Ditolak }\end{array}$ \\
\hline Edit Profile & $\begin{array}{l}\text { Data-data pribadi Admin seperti } \\
\text { username, nama, jabatan dan } \\
\text { password berhasil diubah sesuai } \\
\text { yang diinputkan Admin }\end{array}$ & $\begin{array}{l}\text { Data-data pribadi Admin seperti } \\
\text { username, nama, jabatan dan } \\
\text { password berhasil di update }\end{array}$ & $\begin{array}{l}\text { [x] Diterima } \\
\text { [ ] Ditolak }\end{array}$ \\
\hline Cari data & $\begin{array}{l}\text { Tampil data bencana / kebakaran } \\
\text { sesuai dengan keyword yang } \\
\text { dimasukkan }\end{array}$ & $\begin{array}{l}\text { Tampil data bencana / kebakaran } \\
\text { sesuai dengan keyword yang } \\
\text { dimasukkan }\end{array}$ & $\begin{array}{l}\text { [x] Diterima } \\
\text { [ ] Ditolak }\end{array}$ \\
\hline $\begin{array}{l}\text { Edit Data } \\
\text { (Bencana,kebakaran, } \\
\text { korban, sarana } \\
\text { prasarana, logistik) }\end{array}$ & $\begin{array}{l}\text { Tombol "Simpan" berfungsi dan } \\
\text { data pada tabel bencana berubah } \\
\text { sesuai dengan id yang dipilih oleh } \\
\text { Admin dan data-data lain berubah } \\
\text { sesuai inputan Admin }\end{array}$ & $\begin{array}{l}\text { Tombol "Simpan" berfungsi dan } \\
\text { data pada tabel bencana berubah } \\
\text { sesuai dengan id yang dipilih oleh } \\
\text { Admin dan data-data lain berubah } \\
\text { sesuai inputan Admin }\end{array}$ & $\begin{array}{l}\text { [x] Diterima } \\
\text { [ ] Ditolak }\end{array}$ \\
\hline $\begin{array}{l}\text { Hapus Data } \\
\text { (Bencana,kebakaran, } \\
\text { korban, sarana } \\
\text { prasarana, logistic) }\end{array}$ & $\begin{array}{l}\text { Data yang dipilih terhapus dari } \\
\text { database }\end{array}$ & $\begin{array}{l}\text { Data yang dipilih terhapus dari } \\
\text { database }\end{array}$ & $\begin{array}{l}\text { [x] Diterima } \\
\text { [ ] Ditolak }\end{array}$ \\
\hline Logout & $\begin{array}{l}\text { Admin berhasil keluar dari sistem } \\
\text { dan kembali ke halaman Index }\end{array}$ & $\begin{array}{l}\text { Admin berhasil keluar dari sistem } \\
\text { dan kembali ke halaman Index }\end{array}$ & $\begin{array}{l}\text { [x] Diterima } \\
\text { [ ] Ditolak }\end{array}$ \\
\hline \multicolumn{4}{|c|}{ Hasil Pengujian dengan Data Salah } \\
\hline $\begin{array}{l}\text { Aktivitas } \\
\text { Pengujian }\end{array}$ & Realisasi yang Diharapkan & Hasil Pengujian & Kesimpulan \\
\hline Login & $\begin{array}{l}\text { Sistem menampilkan pesan error / } \\
\text { kesalahan ketika Admin } \\
\text { memasukkan username atau } \\
\text { password yang salah, dan kembali } \\
\text { ke halaman Index }\end{array}$ & $\begin{array}{l}\text { Muncul pesan error / kesalahan } \\
\text { ketika Admin memasukkan } \\
\text { username atau password yang } \\
\text { salah, dan kembali ke halaman } \\
\text { Index }\end{array}$ & $\begin{array}{l}\text { [x] Diterima } \\
\text { [ ] Ditolak }\end{array}$ \\
\hline $\begin{array}{l}\text { Input Data dengan } \\
\text { salah satu kolom ada } \\
\text { yang kosong }\end{array}$ & $\begin{array}{l}\text { Tampil peringatan dan data tidak } \\
\text { masuk ke database }\end{array}$ & $\begin{array}{l}\text { Tampil peringatan dan data tidak } \\
\text { masuk ke database }\end{array}$ & $\begin{array}{l}\text { [x] Diterima } \\
\text { [ ] Ditolak }\end{array}$ \\
\hline
\end{tabular}

Dari hasil pengujian di atas didapatkan bahwa sistem berjalan dengan baik dan memberikan pesan error / peringatan Ketika inputan tidak sesuai. Tampilan dari aplikasi juga telah disesuaikan dengan kebutuhan pengguna dan terbagi menjadi 3 (tiga) sesuai level user-nya yaitu :

1. Tampilan Pengunjung meliputi halaman index, data bencana, data kebakaran, data sarana prasarana dan data logistik (tidak bisa di edit)

2. Form Login : Jika login berhasil maka pengguna akan diarahkan ke halaman sesuai dengan level / hak aksesnya.

3. Tampilan User, meliputi : input data bencana, data kebakaran, data korban bencana dan data korban kebakaran. User juga dapat melihat tampilan data sarana prasana dan logistik, tetapi tidak dapat melakukan proses create, update dan delete.

4. Tampilan Admin , meliputi : input data bencana, data kebakaran, data korban bencana, data korban kebakaran ,sarana prasarana, logistik dan usulan bantuan; update untuk data bencana, kebakaran, korban bencana, korban kebakaran, sarana prasarana dan logistik, serta delete untuk data bencana, kebakaran, korban bencana dan korban kebakaran 
5. Tampilan Super Admin, meliputi : input validasi usulan bantuan; update data user, membuat laporan data bencana, kebakaran, korban bencana, korban kebakaran dan bantuan.

\section{B. Pembahasan}

Pembuatan database

Langkah awal dalam pembuatan database adalah mempersiapkan server yang nantinya akan digunakan untuk penempatan database dan file web. Untuk pembuatan database, digunakan server XAMPP (localhost) sebagai wadah phpMyAdmin.

\section{Membuat trigger}

Trigger merupakan sebuah script MySql yang mengakibatkan terjadinya suatu kejadian seperti INSERT, UPDATE, DELETE secara otomatis setelah kondisi tertentu terpenuhi. Trigger akan dijalankan ketika data baru diinputkan ke tabel (even BEFORE - INSERT) atau setelah data diinputkan ke tabel (AFTER - INSERT).

Pada sistem informasi ini, trigger digunakan untuk membuat id bencana dan id kebakaran dengan awalan / prefix secara otomatis, dengan even BEFORE - INSERT.
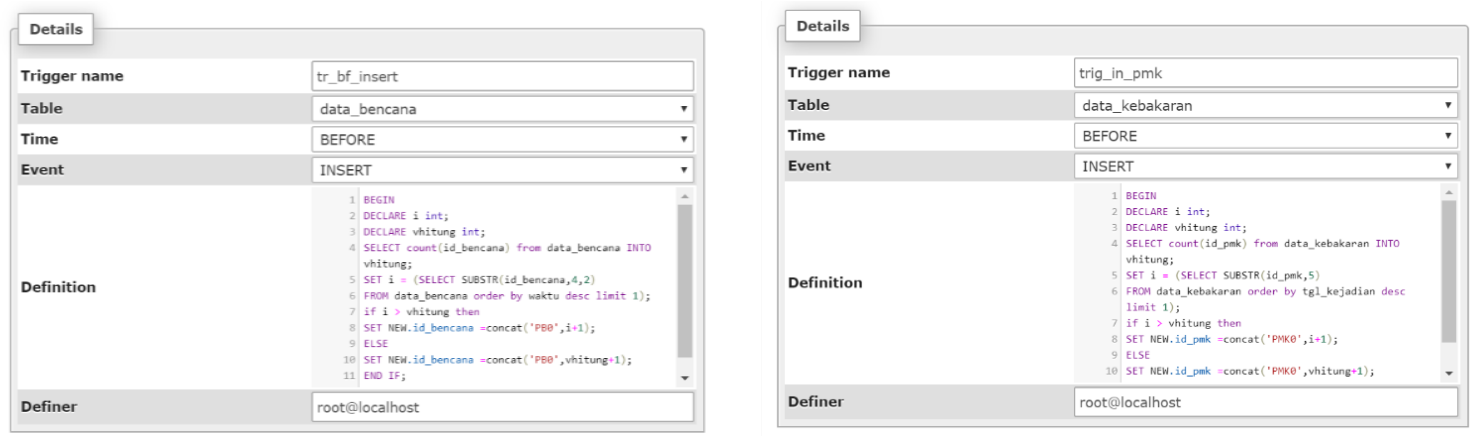

Gambar 4. Trigger pada tabel data_bencana dan kebakaran untuk id_bencana dan id_kebakaran otomatis dengan prefix

Tampilan pada website ini menggunakan Cascading Style Sheets (CSS). Untuk file CSS ini ditulis terpisah dengan file .php sehingga pada script HTML cukup memanggil class nya saja.

Sesuai penjelasan di atas, masing-masing pengguna memiliki hak akses yang berbeda. Berikut ini adalah perbedaan hak akses dari masing-masing pengguna :

Tabel 3. Perbedaan Hak Akses dalam pengelolaan data masing-masing level pengguna

\begin{tabular}{lccc}
\hline \multicolumn{1}{c}{ Data } & User & Admin & Super Admin \\
\hline Data Bencana & $\sqrt{ }$ & $\sqrt{ }$ & $\sqrt{ }$ \\
\hline Data Kebakaran & $\sqrt{ }$ & $\sqrt{ }$ & $\sqrt{ }$ \\
\hline Data Korban Bencana & $\sqrt{ }$ & $\sqrt{ }$ & $\sqrt{ }$ \\
\hline Data Korban Kebakaran & $\sqrt{ }$ & $\sqrt{ }$ & $\sqrt{ }$ \\
\hline Data Usulan Bantuan & & $\sqrt{ }$ \\
\hline Data Sarana Prasarana & & $\sqrt{ }$ \\
\hline Data Logistik & & & $\sqrt{ }$ \\
\hline Data User & & & \multicolumn{2}{c}{} \\
\hline Laporan & & & \\
\hline
\end{tabular}

Halaman utama akan muncul pertama kali ketika pengguna mengakses sistem. Pada halaman index akan langsung tampil box login, sedangkan di bagian atas dan samping terdapat menu bar yang dapat diakses ketika pengguna ingin mengakses website lain. 


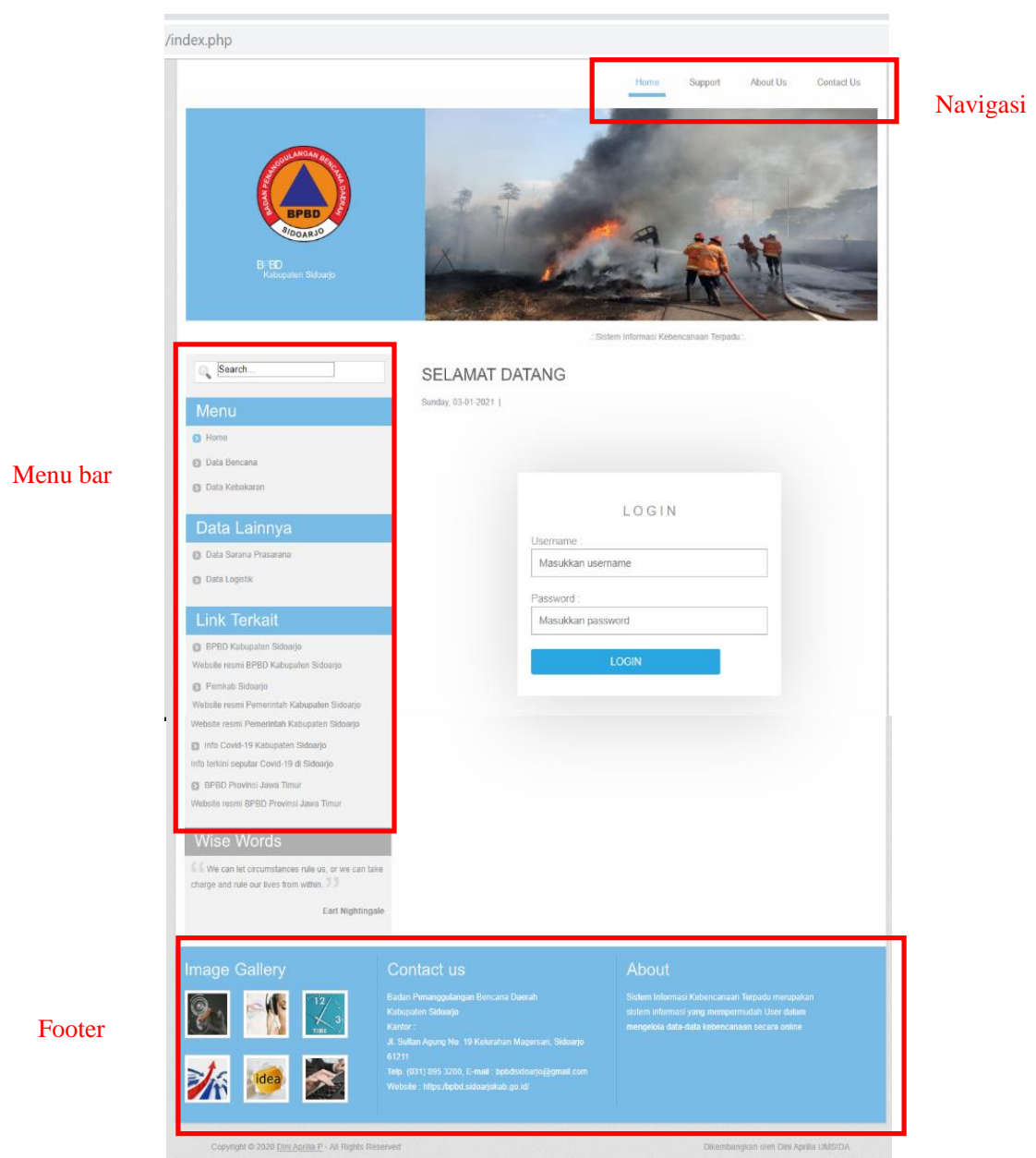

Gambar 5. Halaman utama / index

User dapat mengisi username dan password sesuai dengan yang telah dibuat. Jika berhasil login, maka sistem akan mengarah ke halaman sesuai dengan hak akses user tersebut. Misalnya admin, maka jika login berhasil akan diarahkan ke halaman Home Admin. Jika super admin, maka akan diarahkan ke halaman Home Super Admin, dsb.

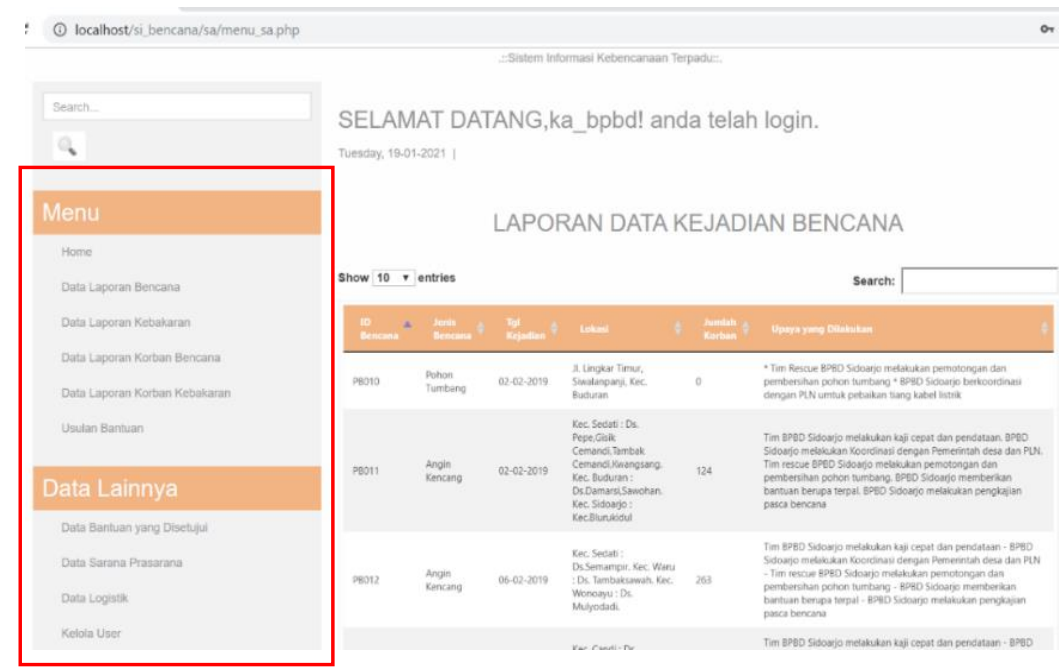

Gambar 6. Halaman Home Super Admin setelah berhasil login

User dapat mencari data dengan kriteria tertentu serta dapat mengunduh laporan berupa file pdf. Dengan menggunakan PDO dan FPDF, database dapat diolah dengan berbagai macam format sesuai dengan kebutuhan, termasuk dalam format PDF. PDO (PHP Database Objects) adalah penambahan fitur pada PHP yang dirancang 
sebagai interface universal untuk akses ke berbagai jenis database [1]. Sedangkan FPDF adalah kelas PHP yang memungkinkan untuk menghasilkan file PDF dengan PHP murni, tanpa menggunakan library PDFlib [5]. Fitur pembuatan laporan terdapat pada user dengan level Super Admin.

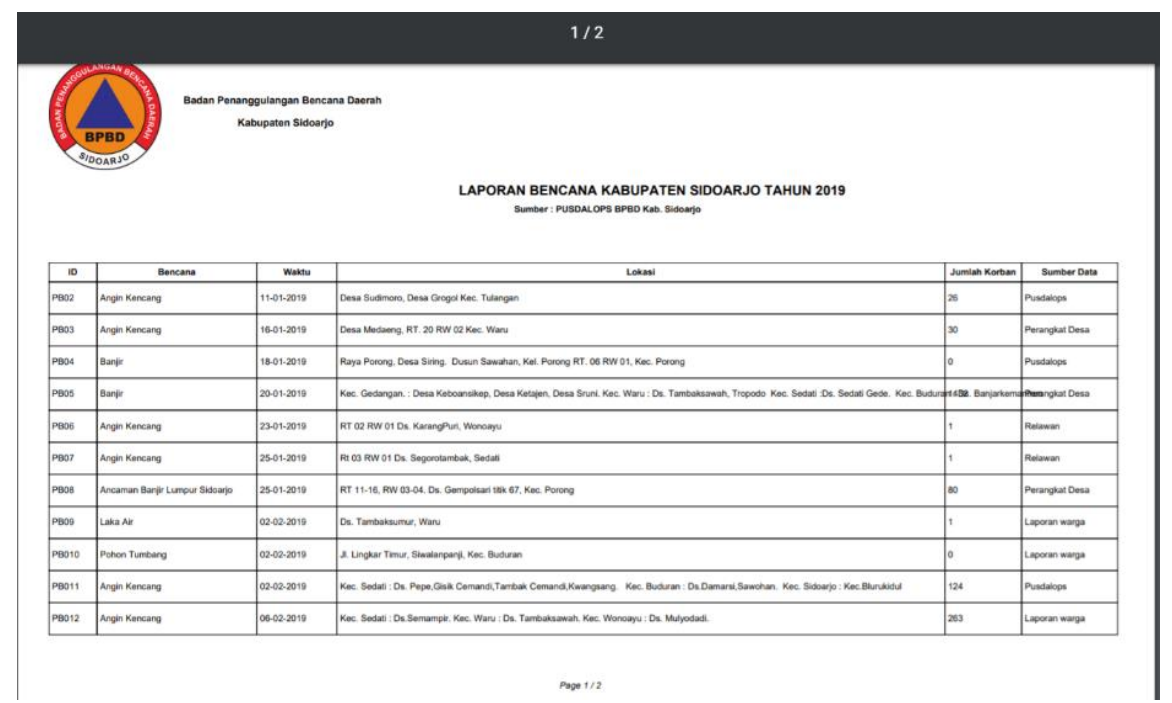

Gambar 7. Dokumen PDF laporan data bencana

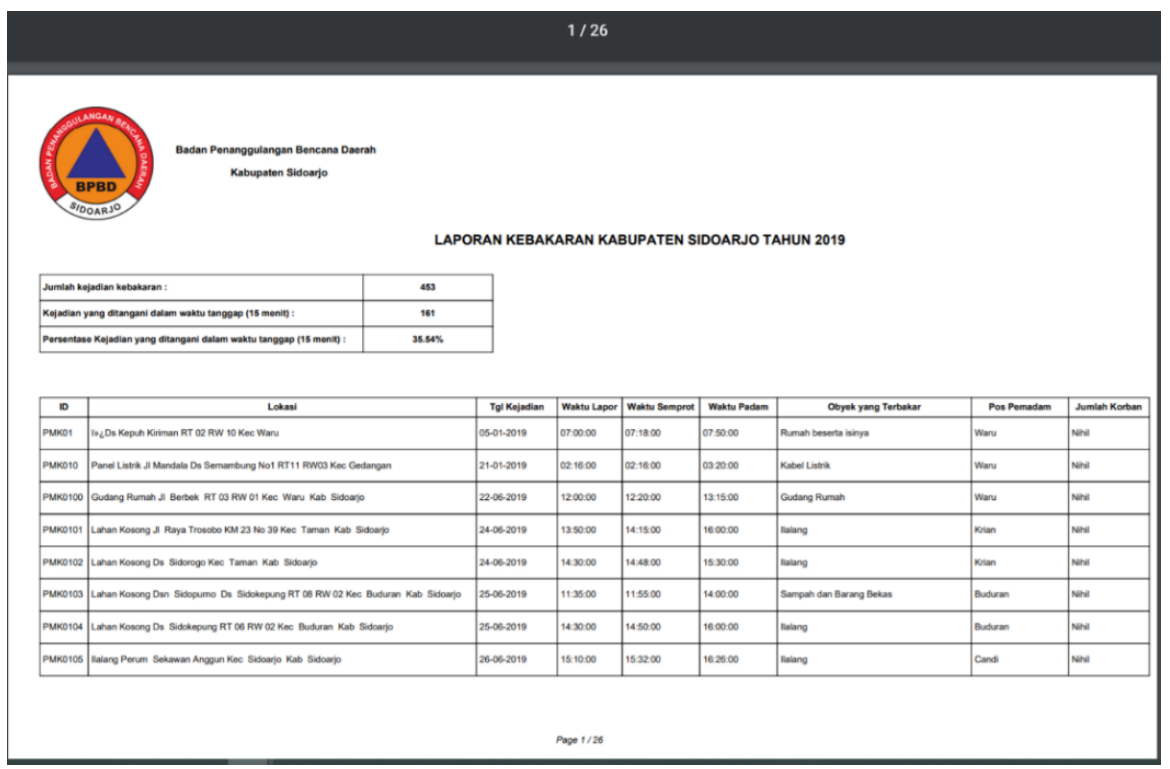

Gambar 8. Dokumen PDF Capaian respon time pada Laporan Kebakaran

Selain kedua data di atas, user juga dapat mengunduh dokumen PDF yang lain yatu data korban, data logsitik, dsb. Untuk mendukung tampilan tabel yang lebih menarik dan responsive, serta untuk fitur pencarian, peneliti menggunakan Bootstrap, Javascript dan JQuery untuk kecepatan eksekusi yang lebih baik [9]. JQuery adalah library Javascript yang dikembangkan untuk membuat penulisan script menjadi lebih ringkas. JQuery hadir untuk mempermudah eksekusi task dan mengatasi permasalahan yang terjadi pada browser [9]. Dengan menggunakan bootstrap, tampilan website dapat di desain menjadi lebih responsif, misalnya tampilan website akan disesuaikan secara otomatis berdasarkan perangkat yang digunakan untuk mengaksesnya [7].

\section{KESIMPULAN}

Penyederhanaan proses bisnis pada penanggulangan bencana dan kebakaran, khususnya untuk aliran data menjadi lebih ringkas. Akurasi data secara integrasi (satu pintu) dan tidak lagi terpisah di masing-masing bidang. Data yang tumpang tindih dapat dihindari. Data kebencanaan dapat diakses dimana saja dan kapan saja, sesuai hak akses user 
Dapat langsung diketahui jumlah kejadian baik bencana maupun kebakaran dalam 1 (satu) tahun. Memudahkan pengguna dalam menampilkan / mem-filter data dengan kriteria tertentu.

\section{REFERENSI}

[1] Andre. (2014). "Tutorial PHP MySQL Part 19 : Pengertian PDO dan Cara Mengaktifkan PDO (PHP Data Objects)". Diakses pada tanggal 17 Januari 2021 melalui https://www.duniailkom.com/tutorial-php-mysqlpengertian-pdo-dan-cara-mengaktifkan-pdo-php-data-objects/

[2] Assocs, J. (1995). “Flowcharts : Plain and Simple”. (Oriel Inc.) Diakses pada tanggal 20 Oktober 2020 melalui https://books.google.co.id/books/about/Flowcharts.html

[3] Edi, D., \& Betshani, S. “Analisis Data dengan Menggunakan ERD dan Model Konseptual Data Warehouse”. Bandung,Jurnal Informatika, 5, 71-85, Juni 2009.

[4] Erawan, L. (2014). Dasar-dasar PHP. Diakses pada tanggal 20 Oktober 2020, melalui Universitas Dian Nusantoro Semarang: https://dinus.ac.id/repository/docs/ajar/1-PHP_DASAR-DASAR.pdf

[5] FPDF Org. (n.d.). FPDF Library PDF Generator. Diakses pada tanggal 17 Januari 2021, melalui http://fpdf.org/

[6] Islami, M., \& Eviyanti,S.Kom.,M.Kom., A. Rancang Bangun Aplikasi Terintegrasi untuk Pelayanan Puskesmas Menggunakan Framework CodeIgniter. Sidoarjo, 2015.

[7] Kaban, R. (2017). Design Website Responsive dengan Bootstrap. Diakses pada tanggal 15 Januari 2021, melalui https://osf.io/c8vhm/download/

[8] Undang-Undang Nomor 24 Tahun 2007.Penanggulangan Bencana. 26 April 2007. Lembaran Negara Republik Indonesia Tahun 2007. Jakarta.

[9] Mc Farlan, D. S. Javascript \& JQuery : The Missing Manual (Second ed.). California: O'Reilly Media Inc. November, 2012.

[10] Parno. (2005). Data Flow Diagram. Diakses pada tanggal melalui Universitas Gunadarma: http://parno.staff.gunadarma.ac.id/Downloads/files/4403/PSI04_DFD.pdf.

[11] Subagia, A. Membuat Web dengan PHP 7 dan Database PDO MySQLi. Jakarta: PT. Elex Media Komputindo. 2016.

[12] Universitas Dian Nusantoro Semarang. (n.d.). Bab 6 Pemodelan Sistem (Context Diagram, Data Flow Diagram). Diakses pada tanggal 24 Oktober 2020, melalui https://dinus.ac.id/repository/docs/ajar/5b._handout-contexdiagram.pdf

[13] Zainudin, A., \& Eviyanti,S.Kom.,M.Kom., A. “Aplikasi Penjualan Tas pada Toko Asri Berbasis Web”. Sidoarjo, September 2016. 